\title{
Remedyto the Shading Effect on Photovoltaic Cell
}

\author{
${ }^{1}$ Ekpenyong, E.E and ${ }^{2}$ Anyasi, F.I \\ ${ }^{1}$ Department of Electrical/Electronic Engineering, Cross River University of Technology, P.M.B 1123, \\ Calabar. Nigeria. \\ ${ }^{2}$ Department of Electrical and Electronics Engineering, Ambrose Alli University, P.M.B 14, Ekpoma, Edo State,
} Nigeria.

\begin{abstract}
Use of by-pass diodes for each PV module may mitigate the negative effect from partial shading. However, this method alone may still face severe energy efficiency degradation caused by the energy loss due to parasitic effects in the EES elements under variable incoming power from the PV modules. Hence, this paper proposes methods to enhance the PV system efficiency and robustness under partial shading. Here, by-pass diodes are connected parallel to a number of solar cells. Under normal operating conditions, the diodes are blocked compared to the voltage generated by the cells. When shading occurs, the reverse of the voltage was observed in that specific section which enables the by-pass diode in parallel to conduct the current. It was observed that; the current of the un-shaded flows through the by-pass diode and the power/voltage characteristics shows a second local maximum. Also, the shaded cell was only loaded with that fraction of power produced by the un-shaded cells of that section.
\end{abstract}

\section{Introduction}

Solar photovoltaic array is formed by series/parallel combination of SPV modules to attain a desired voltage and current level. The major challenge in using a SPV source containing a number of cells in series is to deal with its nonlinear internal resistance. The problem gets complex when the array receives non uniform irradiance or partially shaded. In a larger SPVA, the occurrence of partial shading is common due to tree leaves falling over it, birds or bird litters on the array, shade of a neighbouring construction, and so forth. In a series connected string of cells, all the cells carry the same current. Even though a few cells under shade produce less photon current, these cells are also forced to carry the same current as the other fully illuminated cells. The shaded cells may get reverse biased, acting as loads, draining power from fully illuminated cells. If the system is not appropriately protected, hot-spot problem [1] can arise and in several cases, the system can be irreversibly damaged. Nowadays there is an increasing trend to integrate the SPV arrays at the design level in the building itself. In such cases it is difficult to avoid partial shading of array due to neighbouring buildings throughout the day in all the seasons. In conventional SPV systems, these shadows lower the overall generation power to a larger degree than what is expected. Hence the SPV installation cost is increased, because the number of SPV modules must be increased [2] and as a result, SPV power generation will be less attractive. This makes the study of partial shading of SPV modules a key issue. Moreover it is very important to understand the characteristics of SPVA under partial shaded conditions to use SPV installations effectively under all conditions. In recent years, the impact of partial shading on the SPV array performance has been widely discussed [3-6]. With a physical SPV module it is difficult to study the effects of partial shading since the field testing is costly, time consuming and depends heavily on the prevailing weather conditions. Moreover, it is difficult to maintain the same shade under varying numbers of shaded and fully illuminated cells throughout the experiment. However it is convenient to carry out the simulation study with the help of a computer model. In most of the studies [7-10], the effect of partial shading in reducing the output power of the SPVA has been discussed. But little attention has been paid to the power dissipated by the shaded cells affecting the array life and utilization of the array for the worst shaded case. The harmful effects in basic configurations and their comparison have been discussed in [11].

Common use of bypass diodes in anti- parallel with the series-connected SPV modules can partially mitigate the power reduction due to partial shadow [11]. In such cases a more sophisticated Maximum Power Point Tracking (MPPT) algorithms capable to disregard local power maximums is required [12-14]. Alternatively, the maximum available DC power can be improved if the connection of the SPV modules can be reconfigured such that panels with similar operating conditions are connected in the same series string. Moreover the parallel configuration should be dominant under partial shaded conditions [3-5]. However, high output current at low voltage in parallel configuration will have to be properly conditioned to the required level by using suitable DC-DC converter. Hence it is required to opt for derived configurations. In this paper, for different configuration types, the generalized MATLAB programs have been developed which are capable of simulating any number of modules connected in series, parallel or combined for any type of shading patterns 
and any number of bypass diodes. The comparative study is made among the configurations and conclusions have been presented.

Simulation of Configurations under Partial Shaded Conditions [15] proposed a numerical algorithm to simulate the mismatch in individual SPV cells and their shading levels. But it requires each element to be represented by a mathematical expression. Even though this produces accurate results, the model is complex and requires more computation time and higher memory requirement.Developed a computational network analysis approach to compare the configurations.Proposed a module-based and cell-based model for analyzing the array configurations, [16].Proposed a neural network-based model to investigate the effects of passing clouds on a grid-connected SPV system using battery storage. The importance of selecting the proper size of the SPV array and batteries in such systems has been discussed by [10]. It is required for the stable operation of SPV system with a sudden and large change in SPV power because of irradiance variation, caused by shading, and so forth. Shading caused due to passing clouds also has a financial claim on the utility. Jewell and Unruh [11] have carried out an economic analysis to estimate the cost of the fluctuations in power generation from a SPV source. Based on the literature it is understood that not only the size of the SPVA but also its configuration that significantly affects its power output, and therefore, the performance of the system under partially shaded conditions. From the above discussion, it may be concluded that, while it is very important to model, study, and understand the effects of shading on SPV arrays, a simple tool is not available for the purpose. Therefore, it is felt that there is a need for a flexible, interactive, and comprehensive simulation model capable to predict the SPV characteristics (including multiple peaks) and output power under partially shaded conditions. [12, 13] have proposed a MATLAB based-simulator cum learning tool to understand the characteristics of a large SPV array by considering the model in I quadrant given in Figure 2. They have developed a model for SP configuration with bypass diodes. The model used by [12] neglects the effect of shunt resistance. [14] Discussed the impact of under partial shaded conditions. In order to obtain the realistic model which provides the practical maximum power point values, it is mandatory to include the effect of varying with respect to environmental parameters particularly for crystalline type SPV modules. Hence the proposed model includes the insolationdependent shunt resistance and the basic model equations used by [12] have been replaced by the improved model equations used by [15].

\section{Methodology}

Given that the total estimated load in kilowatts $(\mathrm{KW})$ is $915 \mathrm{KW}$. To effectively and efficiently select other components, for example the inverter, we must convert the power in kilowatts to the kilovolt-ampere (KVA). The conversion factor below is applied.

$\mathrm{KVA}=\mathrm{KW} / 0.8$

Therefore; $915 \mathrm{~W} / 08=1143.75 \mathrm{VA}$, which is approximately $1.5 \mathrm{KVA}$

Based on the estimated loads, the sizes and capacity of the system components were determined, and are shown in the Table 1.

Table 1: System Components and Capacity

\begin{tabular}{|l|l|l|l|l|}
\hline S/N & EQUIPMENT & QUANTITY & $\begin{array}{l}\text { CAPACITY } \\
\text { EQUIPMENT }\end{array}$ & PER \\
\hline 1. & SOLAR PANEL & $4(80 \mathrm{w} \times 4)$ & 320 WATT & $320 \mathrm{WATTS}(24 \mathrm{~V})$ \\
\hline 2. & $\begin{array}{l}\text { CHARGE } \\
\text { CONTROLLER }\end{array}$ & 1 & $20 \mathrm{AMPS} / 24 \mathrm{~V}$ & $20 \mathrm{AMPS} / 24 \mathrm{~V}$ \\
\hline 3. & DEEP CYCLE BATTERY & 2 & $200 \mathrm{AH}, 12 \mathrm{~V}$ & $200 \mathrm{AH}, 24 \mathrm{~V}$ \\
\hline 4. & INVERTER & 1 & $1.5 \mathrm{KVA}(24 / 220 \mathrm{~V})$ & $1.5 \mathrm{KVA}(24 \mathrm{~V} / 220 \mathrm{~V})$ \\
\hline
\end{tabular}

This solar energy system is designed to supply constant power to the estimated loads for an average working period of about six (8) hours daily, for the entire functioning life of the system.

\section{Remedy to the Effect of Shading}

By-pass diodes are connected parallel to a number of solar cells.

Under normal operating conditions, the diodes are blocked compared to the voltage generated by the cells. When shading occurs, the reverse of the voltage can be observed in that specific section which enables the bypass diode in parallel to conduct the current.

When this happens, the following results occur;

- The current of the un-shaded flows through the by-pass diode and the power/voltage characteristics shows a second local maximum.

- The shaded cell is only loaded with that fraction of power produced by the un-shaded cells of that section

- When the number of cells which are bridged by the by-pass is not too high, the level of breakthrough voltage will not be reached. 


\section{DESIGN CONSIDERATION}

To effectively design the photovoltaic system, certain factors were considered. These factors include;

(a) Total load and energy demand.

The total load and energy demand enable us to determine the capacity or sizes of the following equipment:

(i) Size of the inverter.

(ii) Size of battery bank.

(iii) Size of the solar panel.

(b) Space for solar panels.

(c) Clients financial status.

\section{Determination of Total Load and Energy Demand}

There are four issues that arose in the design of the system.

1. That the load on the system is not constant over the period of the day

2. That the daily load varies over the year

3. That the energy available from the sun source may vary from time to time during the day

4. That the available energy radiant from the sun source varies from day to day during the year.

If the system is based on photovoltaic module, then a comparison should be made between the actual energy demand and the available energy from the sun.

In all cases, the first step in system sizing is to estimate the load placed on the system and to examine the actual requirements from the system.

This is done by establishing an AC and DC load assessment sheets. But since the project is aimed at the use AC, the AC load assessment shall be considered.

\section{Load Assessment Procedure}

It is imperative that the assessment process captures the following, as seen in Table 1

PRPA $\times \mathbf{N}=$ TPRPA (Watts).

Where PRPA is Power Rating per Appliance.

$\mathrm{N}$ is Number of each appliance to be powered.

NOTE: $N$ is not constant.

TPRPA $\times \mathbf{T}=\mathbf{E}(\mathbf{W h r})$.

Where $E$ is Energy in Watt-hour (Whr).

$\mathrm{T}$ is back-up hour.

NOTE: $\mathrm{T}=8$ hours

Table 2: Load assessment sheet showing column 1 to 3

\begin{tabular}{|l|l|l|}
\hline \multicolumn{1}{|c|}{ Column 1 } & \multicolumn{1}{|c|}{ Column 2 } & \multicolumn{1}{c|}{ Column 3 } \\
\hline Appliances & Power Rating per appliance (Watts) & $\begin{array}{l}\text { Number } \\
\text { Of each appliance to be } \\
\text { powered }\end{array}$ \\
\hline Energy saving bulbs & 10 & 3 \\
\hline Standing fan & 30 & 3 \\
\hline 14 inch TV set & 40 & 3 \\
\hline Laptop computer & 90 & 3 \\
\hline Phone charger & 15 & 3 \\
\hline Desktop and printer & 360 & 1 \\
\hline
\end{tabular}

Table 3: Load assessment sheet showing column 1 to 5

\begin{tabular}{|l|l|l|l|l|}
\hline Column 1 & \multicolumn{1}{|c|}{ Column 2 Column 3 } & Column 4 \\
\hline Appliances & $\begin{array}{l}\text { Power Rating per appliance } \\
\text { (Watts) }\end{array}$ & $\begin{array}{l}\text { Number } \\
\text { Of each appliance to be } \\
\text { powered }\end{array}$ & $\begin{array}{l}\text { Total power rating per } \\
\text { appliance (Watts) }\end{array}$ & Back-up hour \\
\hline Energy saving bulbs & 10 & 3 & 30 & 8 \\
\hline Standing fan & 30 & 3 & 90 & 8 \\
\hline 14 inch TV set & 40 & 3 & 120 & 8 \\
\hline Laptop computer & 90 & 3 & 270 & 8 \\
\hline Phone charger & 15 & 3 & 45 & 8 \\
\hline Desktop and printer & 360 & 3 & 360 & 8 \\
\hline
\end{tabular}

Column 4 above is gotten from equation. ... .1 
Table 4: Load assessment sheet showing column 1 to 6

\begin{tabular}{|l|l|l|l|l|l|}
\hline Column 1 & Column 2 & Column 3 & Column 4 & Column 5 & Column 6 \\
\hline Appliances & $\begin{array}{l}\text { Power rating per } \\
\text { appliance (Watts) }\end{array}$ & $\begin{array}{l}\text { Number } \\
\text { of each appliance to } \\
\text { be powered }\end{array}$ & $\begin{array}{l}\text { Total power rating } \\
\text { per appliance } \\
\text { (Watts) }\end{array}$ & $\begin{array}{l}\text { Back-up hour } \\
\text { per appliance }\end{array}$ \\
\hline $\begin{array}{l}\text { Energy saving } \\
\text { bulbs }\end{array}$ & 10 & 3 & 30 & 8 & 240 \\
\hline Standing fan & 30 & 3 & 90 & 8 & 720 \\
\hline 14 inch TV set & 40 & 3 & 120 & 8 & 960 \\
\hline Laptop computer & 90 & 3 & 270 & 8 & 2160 \\
\hline Phone charger & 15 & 3 & 360 & 8 & 360 \\
\hline $\begin{array}{l}\text { Desktop and } \\
\text { printer }\end{array}$ & 360 & 1 & & 8 & 2880 \\
\hline
\end{tabular}

Column 6 above is gotten from........................................

Total estimated load $=\sum$ of total power rating per appliance (Watts)........3

$=30+90+120+270+45+360$

$=915$ Watts

The estimated load in VA $=$ Total estimated load $\div$ Power factor. .4

$$
\begin{aligned}
& =915 \div 0.8 \\
& =1143.75 \mathrm{VA}
\end{aligned}
$$

The total energy demand $=\sum$ of energy $($ Whr) per appliance

$=240+720+960+2160+360+2880$

Total energy demand $=7320 \mathrm{Whr}$

\section{Size of the Inverter.}

Inverters are rated in Kilo Volt Amps (KVA). The total estimated load above, when converted to its KVA equivalent was calculated as $1.1438 \mathrm{KVA}$. From this value, a $1.2 \mathrm{KVA}$ inverter would be required to satisfy the load requirement.

A 1.5KVA inverter was designed to enable the system cope with the surge start-up of some equipment such as the television sets and computer monitor, to compensate for power losses and to allow for additional loads to be energized as may be required, without posing danger to the life span and proper functioning of the system.

Due to the complex circuitry involved in the design, and the possibility of voltage drops across each circuit component, inverters above 915Watts must be supplied with DC voltages at 24 Volts and above. The more power required, the more the DC Voltage demand

Furthermore, inverters have DC input voltages such as; 6volts, 12volts, 24volts, and 48volts. My decision to use a 24 volts inverter is to enable more power to be transferred from the low voltage to the high voltage side of the transformer in the inverter and also, to ensure a stable and pure sinusoidal waveform of the AC output voltage.

\section{Size of the Battery Bank}

Batteries are normally 12 volts, rated in Ampere Hours. Since the inverter requires a 24 volts dc input, our battery bank would therefore be a combination of two 12 volts batteries connected in series. To determine the amp hour capacity of the battery bank, the total energy demand and the total back-up hours need to be considered.

Total energy demand for the system was computed as $5490 \mathrm{Wh}$.

$\left(\frac{\text { total Energy demand } \times \text { days of back-up }}{\text { battery voltage }}\right) \div(0.707 \times 1.1) \ldots \ldots \ldots \ldots 6$

Where; 1.1 is the battery bank constant.

$=\left(\frac{7320 \times 1}{24}\right) \div(0.707 \times 1.1)=305 \div 0.78$

$=392.18$ Ah at 24 Volts.

An approximately $400 \mathrm{Ah}$ at 24 Volts battery would therefore be required for the system. My decision to use a $400 \mathrm{Ah}$ battery at the same voltage is to increase back-up time. I would therefore require two $12 \mathrm{Volts}, 200 \mathrm{Ah}$ batteries connected in series.

\section{Size of the Solar Panel}

Since the system is designed to work independently i.e. as standalone, the energy required from the panels would just be that sufficient to charge the battery.

Since the combined battery voltage is 24 volts. The solar panel would also have to supply approximately the same voltage. Solar panels are designed to give an output voltage of 12 volts per panel, therefore four panels, wired in series and parallel was used to produce 24 volts sufficient to charge the battery. 
This configuration was used to increase the current. Another consideration for selecting the solar panel is the battery charging current. The solar panel(s) must also provide the necessary charging current for the battery bank. Deep cycle batteries require a charging current of approximately 10Amps. Therefore each of the panels would have to be rated at 10Amps or even higher to compensate for losses that may arise due to uneven distribution of the radiant energy on the panels.

\section{Size of the Charge Controller}

Charge controllers regulate the charge entering the battery from the solar panels. They also ensure that the batteries are not over charged and that they are not over drained during use. Solar regulators often short circuit the solar panel input when regulating. This however does not damage the panels but implies that the solar regulator must be sized to handle about $125 \%$ of the rated short circuit current of the solar panel.

Since the system voltage for the DC section is 24 Volts, a 24 volt charge controller would be required. The current rating of the regulator is determined below;

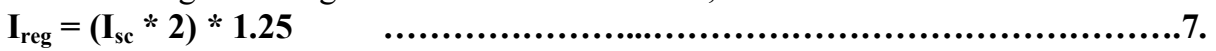

Where, $I_{\text {reg }}=$ current rating of the regulator; $I_{s c}=$ short circuit current of the solar panel.

Given that the short circuit rating of the panels used in this project is 7.4 Amps. We must recall that the panels are wired in series/parallel, so the output current remains the same

Therefore; $\mathrm{I}_{\mathrm{reg}}=(7.4 * 2) * 1.25$

$$
\begin{aligned}
& =14.8 * 1.25 \\
& =18.5 \text { Amps. }
\end{aligned}
$$

A 20Amp charge controller would therefore be required.

The table below summarizes the sizes and capacities of the various components for the system in this project.

Table 5: Sizes and Capacities of the Various Components of the System.

\begin{tabular}{|l|l|l|l|l|}
\hline S/N & Equipment & Quantity & Capacity per Equipment & Combined Capacity \\
\hline 1. & Solar panel & 4 & 80 Watts & $320 \mathrm{~W} / 24 \mathrm{~V}$ \\
2. & Charge Controller & 1 & $20 \mathrm{Amps} / 24 \mathrm{Volts}$ & $20 \mathrm{Amps} / 24 \mathrm{~V}$ \\
3. & Deep cycle Battery & 2 & $200 \mathrm{AH} / 12 \mathrm{Volts}$ & $400 \mathrm{AH} / 24 \mathrm{~V}$ \\
4. & Pure sine wave Inverter & 1 & $1.5 \mathrm{KVA} / 24 \mathrm{Volts}$ & $1.5 \mathrm{KVA} / 24 \mathrm{~V}$ \\
\hline
\end{tabular}

\section{Space for Panels.}

Optimum orientation of solar panels gives a better output performance when the maximize the time that they face the sun. This is dependent on the way they are mounted. The method could be either by the use of solar trackers which are attached to the panel installation and they move the photovoltaic panels to track the sun, or by static mounted systems, which can be optimized through the analysis of the sun path. The space for solar panel mounting should be such that, the sun strikes directly on the panels.

Before mounting a solar panel, a proper check should be taken into consideration as to where will be suitable for the panels to attract the radiation of the sun.

\section{TESTS AND RESULTS OF PV SYSTEM}

\section{Tests}

Before carrying out tests on the system, the following precautions were taken.

i. I used safety helmets, gloves and goggles for eye protection.

ii. I ensured that all labels and safety signs specified in the plans were in place.

iii. I verified that all disconnector switches (from the main AC disconnect all the way through to the combiner fuse switches) are in the open position and tag each box with a warning sign to signify that work on the system is in progress.

The following general tests were performed on all the parts of the system installation as required.

i. Voltage tests (all)

ii. Continuity tests (wiring and cable terminations)

iii. Frequency tests (Mains supply and inverter output)

iv. Short circuit and overload tests (inverter, load, wiring and cable terminations)

v. Polarity tests (all)

\section{Solar Panel Test}

The tests performed on the solar panels are summarized in the table below.

NOTE: All measured values was taken on the $13^{\text {th }}$ November, 2012 as shown in Table 6 and 7 
Table.6: Solar Panel Tests

\begin{tabular}{|c|c|c|c|c|c|}
\hline S.N & Name of test & $\begin{array}{l}\text { Rated value (from } \\
\text { name plate) }\end{array}$ & $\begin{array}{l}\text { Measured value per } \\
\text { panel }\end{array}$ & $\begin{array}{l}\text { measured value for four } \\
\text { panels in series/parallel }\end{array}$ & Remarks \\
\hline 1 & Open circuit voltage & $21.3 \mathrm{~V}$ & $18.7 \mathrm{~V}$ & $38.5 \mathrm{~V}$ & $\begin{array}{lr}\text { Varies } & \text { with } \\
\text { amount } & \text { of } \\
\text { sunlight } & \end{array}$ \\
\hline 2 & Peak voltage & $17.1 \mathrm{~V}$ & $18.7 \mathrm{~V}$ & $38.5 \mathrm{~V}$ & “" \\
\hline 3 & Peak current & $4.67 \mathrm{~A}$ & NIL & 7.35 & “ \\
\hline 4 & Short circuit current & $5.3 \mathrm{~A}$ & NIL & NIL & " \\
\hline 5 & Max. system voltage & $600 \mathrm{~V}$ & NIL & NIL & " \\
\hline 6 & Peak power & $80 \mathrm{~W}$ & $70.75 \mathrm{~W}$ & $282.98 \mathrm{~W}$ & "“ \\
\hline
\end{tabular}

Charge regulator, battery and Inverter tests.

With all the appliances connected but with the load still disconnected the results for this test is summarized in the table below.

Table.7: Charge regulator, battery and inverter tests

\begin{tabular}{|l|l|l|l|l|}
\hline S.N & Equipment & Input voltage & Output voltage & $\begin{array}{l}\text { Output } \\
\text { frequency }\end{array}$ \\
\hline 1 & Charge regulator & $24-38.5 \mathrm{~V} \mathrm{dc}$ & $28 \mathrm{~V} \mathrm{dc}$ & NIL \\
\hline 2 & Battery (2 batteries in series) & $28 \mathrm{~V} \mathrm{dc}$ & $28 \mathrm{~V} \mathrm{dc}$ & NIL \\
\hline 3 & Inverter & $28 \mathrm{~V} \mathrm{dc}$ & $224.5 \mathrm{~V} \mathrm{ac}$ & $50.04 \mathrm{HZ}$ \\
\hline
\end{tabular}

\section{PV characteristics.}

To know the characteristic of a PV, hourly readings was taken for 10hours, values for Voltage and Current using Voltmeter and Ammeter connected in parallel with the solar array was gotten. The values of Power were gotten from calculation using the formula:

$\mathbf{P}=\mathbf{I V}$..... . .8

Where, $\mathrm{P}$ is Power,

I is Current and

$\mathrm{V}$ is Voltage.

The table below shows the values of Voltage, Current and Power at different time of the day. These values were taking for three days and the average was used to plot the graphs to show the characteristics of a PV.

Table: 8: Measured values for PV characteristics without shading. Day1, $13^{\text {th }}$ November, 2012.

\begin{tabular}{|l|l|l|l|l|l|l|l|l|l|}
\hline Time (Hours) & 8 & 9 & 10 & 11 & 12 & 13 & 14 & 15 & 16 \\
\hline $\begin{array}{l}\text { Voltage } \\
\text { (Volts) }\end{array}$ & 26.7 & 38.5 & 36.1 & 35.5 & 35.5 & 37.5 & 38.1 & 34.8 & 37.2 \\
\hline Current (A) & 2.17 & 7.35 & 4.57 & 2.97 & 1.97 & 4.42 & 4.17 & 2.38 & 3.01 \\
\hline Power (Watts) & 57.94 & 282.98 & 164.98 & 105.44 & 69.94 & 165.75 & 158.88 & 82.82 & 111.97 \\
\hline
\end{tabular}

Table: 9: Measured values for PV characteristics without shading. Day $2,15^{\text {th }}$ November, 2012.

\begin{tabular}{|l|l|l|l|l|l|l|l|l|l|l|}
\hline Time (Hours) & 8 & 9 & 10 & 11 & 12 & 13 & 14 & 15 & 16 & 17 \\
\hline $\begin{array}{l}\text { Voltage } \\
\text { (Volts) }\end{array}$ & 26.30 & 38.50 & 39.60 & 37.50 & 37.40 & 38.50 & 38.80 & 37.80 & 38.20 & 37.80 \\
\hline Current (A) & 1.69 & 3.50 & 9.62 & 3.58 & 8.91 & 10.36 & 8.86 & 1.86 & 3.86 & 3.50 \\
\hline Power (Watts) & 44.45 & 134.75 & 380.95 & 132.38 & 333.23 & 398.86 & 343.77 & 70.31 & 134.46 & 131.25 \\
\hline
\end{tabular}

Table: 10: Measured values for PV characteristics without shading. Day 3, 16 ${ }^{\text {th }}$ November, 2012.

\begin{tabular}{|l|l|l|l|l|l|l|l|l|l|l|}
\hline Time (Hours) & 8 & 9 & 10 & 11 & 12 & 13 & 14 & 15 & 16 & 17 \\
\hline $\begin{array}{l}\text { Voltage } \\
\text { (Volts) }\end{array}$ & 31.20 & 40.10 & 40.80 & 40.40 & 40.50 & 39.50 & 39.10 & 25.60 & 25.90 & 29.50 \\
\hline Current (A) & 1.05 & 5.05 & 7.52 & 7.65 & 8.50 & 10.16 & 7.30 & 1.35 & 2.10 & 1.02 \\
\hline Power (Watts) & 32.76 & 202.51 & 306.82 & 309.10 & 344.25 & 401.32 & 285.43 & 34.56 & 54.39 & 30.10 \\
\hline
\end{tabular}

Table: 11: Average values for PV characteristics without shading. $17^{\text {th }}$ November, 2012

\begin{tabular}{|l|l|l|l|l|l|l|l|l|l|l|}
\hline Time (Hours) & 8 & 9 & 10 & 11 & 12 & 13 & 14 & 15 & 16 & 17 \\
\hline $\begin{array}{l}\text { Voltage } \\
\text { (Volts) }\end{array}$ & 28.07 & 39.03 & 38.83 & 37.80 & 37.80 & 38.60 & 38.70 & 32.7 & 33.80 & 30.60 \\
\hline Current (A) & 1.64 & 5.30 & 7.24 & 4.73 & 6.46 & 8.31 & 6.78 & 1.86 & 2.88 & 1.82 \\
\hline Power (Watts) & 45.05 & 206.75 & 208.25 & 182.31 & 249.14 & 321.98 & 262.69 & 62.56 & 100.27 & 61.43 \\
\hline
\end{tabular}


Non-Shaded Characteristics.

III. Results

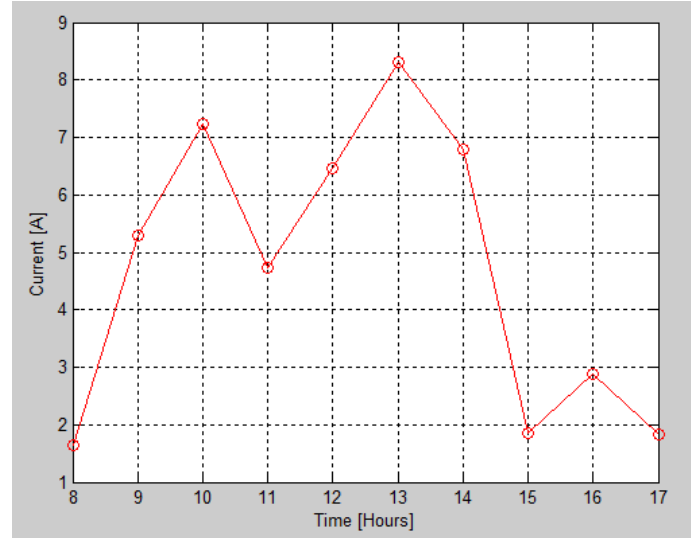

Graph of Current against Time

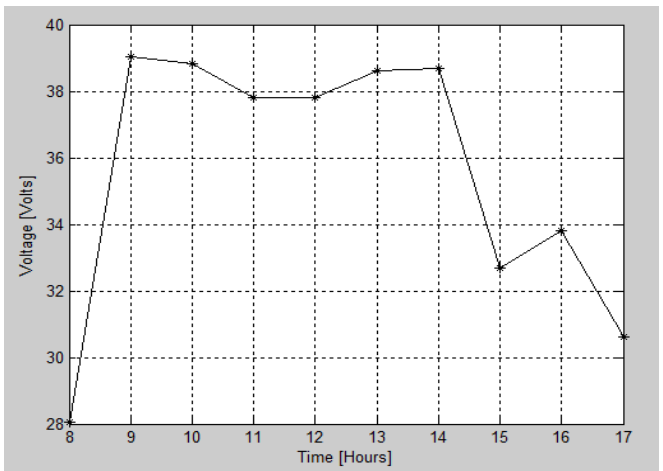

Graph of Voltage against Time

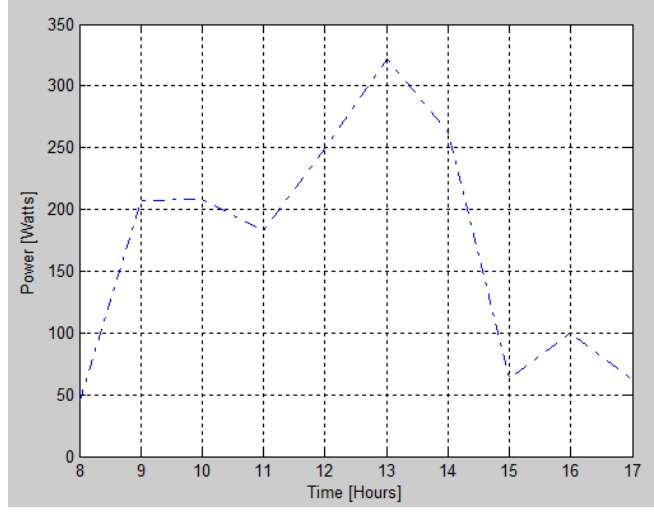

Graph of Power against Time

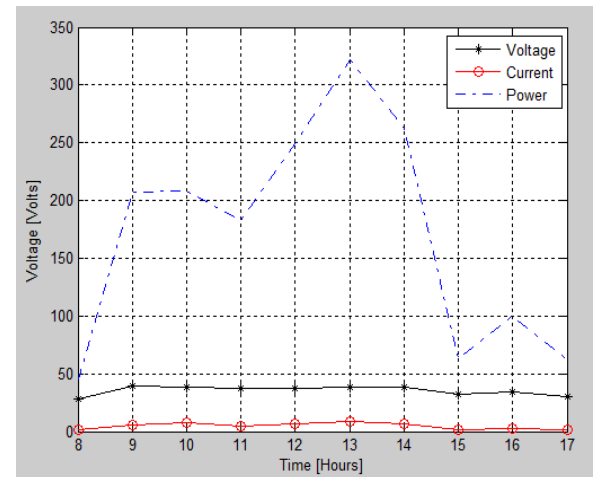

Graph of Current, Voltage and Power against Time

Depth of discharging of battery

It is imperative that the rate at which the battery discharge be assessed. Therefore Depthof dischargingof battery $=\frac{\text { Dailytotalload }(\mathrm{Ah})}{\text { Capacityofbattery }(\mathrm{Ah})} \ldots \ldots \ldots \ldots \ldots \ldots \ldots . . . . . . . . . .9$ 
It was noticed that the load varies from day to day, time to time, therefore the depth of discharging assessment procedure was calculated based on full load, half load and one third load as seen.

Daily total load at full load $=7320 \mathrm{Wh}$

Daily total load at half load $=\frac{7320}{2}=3660 \mathrm{Wh}$

Daily total load at one-third of load $=\frac{7320}{3}=2440 \mathrm{Wh}$

To convert from Wh to Ah:

$\mathbf{A h}=\frac{W h}{\boldsymbol{V}}$

Where Ah $=$ Ampere hour

$\mathrm{Wh}=$ Watt hour

$\mathrm{V}=$ Battery Voltage

From equation 10 we have that;

For full load $=\frac{7320 \mathrm{Wh}}{24 \mathrm{~V}}=305 \mathrm{Ah}$

At half load $=\frac{3600 \mathrm{Wh}}{24 \mathrm{~V}}=152.5 \mathrm{Ah}$

At one third load $=\frac{2440 \mathrm{Wh}}{24}=101.6667 \mathrm{Ah}$

\section{From equation 9 we have that;}

Depth of discharge at full load $=\frac{305 \mathrm{Ah}}{400 \mathrm{Ah}}=0.7625$

Dept of discharging at half load $=\frac{152.5 \mathrm{Ah}}{400 \mathrm{Ah}}=0.3813$

Dept of discharging at one third load $=\frac{101.6667 \mathrm{Ah}}{400 \mathrm{Ah}}=0.2542$

After the installation was completed and testing carried out, it was seen that the photovoltaic system worked perfectly well.

From the graph above, it was noticed that:

1. That the energy available from the sun source varies from time to time during the day

2. That the available energy radiant from the sun source varies from day to day during the year.

3. That the Voltage, current and power due to radiant from the sun source varies from time to time, day to day and year to year.

PERFORMANCE: When a 24 Volt bulb was connected to the output of each of the panels, the bulb lit.

\section{Conclusion}

A typical solar module consists of series connection of solar cells to get practically utilisable voltage. A number of such modules are connected together in series and parallel to get the requisite power. From the results and inferences from this work, it is concluded that there is a substantial power loss due to non-uniform illumination of a series string. The power generated by highly illuminated cells is wasted as a heat in the poorly illuminated cells. Hence, this paper proposes methods to enhance the PV system efficiency and robustness under partial shading. Here, by-pass diodes were connected parallel to a number of solar cells. Under normal operating conditions, the diodes are blocked compared to the voltage generated by the cells. When shading occurs, the reverse of the voltage was observed in that specific section which enables the by-pass diode in parallel to conduct the current. It was observed that; the current of the un-shaded flows through the by-pass diode and the power/voltage characteristics shows a second local maximum. Also, the shaded cell was only loaded with that fraction of power produced by the un-shaded cells of that section

\section{References}

[1] V. Quaschning and R. Hanitsch,"Numerical simulation of current-voltage characteristics of photovoltaic systems with shaded solar cells," Solar Energy, vol. 56, no. 6, pp. 513-520, 1996.

[2] J. H. R. Enslin, M. S. Wolf, D. B. Snyman, and W. Swiegers, "Integrated photovoltaic maximum power point tracking converter," IEEE Transactions on Industrial Electronics, vol. 44, no. 6, pp. 769-773, 1997.

[3] W. Herrmann, W. Wiesner, and W. Vaassen, "Hot spot investigations on PV modules - new concepts for a test standard and consequences for module design with respect to bypass diodes," in Proceedings of the 26th IEEE Photovoltaic Specialists Conference, pp. 1129-1132, October 1997.

[4] N. D. Kaushika and N. K. Gautam, "Energy yield simulations of interconnected solar PV arrays," IEEE Transactions on Energy Conversion, vol. 18, no. 1, pp. 127-134, 2003.

[5] M. Klenk, S. Keller, L. Weber et al., "Investigation of the hotspot behaviour and formation in crystalline silicon Power cells, PV in Europe, From PV technology to energy solutions," in Proceedings of the International Conference, pp. 272-275, 2002.

[6] A. Woyte, J. Nijs, and R. Belmans, "Partial shadowing of photovoltaic arrays with different system configurations: literature review and field test results," Solar Energy, vol. 74, no. 3, pp. 217-233, 2003.

[7] H. S. Rauschenbach, "Electrical output of shadowed solar arrays," IEEE Transactions on Electron Devices, vol. 18, no. 8, pp. 483490, 1971. 
[8] M. C. Alonso-Garc'ia, J. M. Ruiz, and W. Herrmann, “Computer simulation of shading effects in photovoltaic arrays," Renewable Energy, vol. 31, no. 12, pp. 1986-1993, 2006.

[9] M. C. Alonso-Garc'1a, J.M. Ruiz, and F. Chenlo, "Experimental study of mismatch and shading effects in the I-V characteristic of a photovoltaic module," Solar Energy Materials and Solar Cells, vol. 90, no. 3, pp. 329-340, 2006.

[10] E. Karatepe, M. Boztepe, and M. Colak "Development of suitable model for characterizing photovoltaic arrays with shaded solar cells," Solar Energy, pp. 329- 340, 2007.

[11] R. Ramaprabha and B. L. Mathur "Effect of shading on series and parallel connected solar PV modules," Journal of Modern Applied Science, vol. 3, no. 10, pp. 32-41, 2009.

[12] W. Xiao, N. Ozog, and W. G. Dunford, "Topology study of photovoltaic interface for maximum power point tracking,"IEEE Transactions on Industrial Electronics, vol. 54, no. 3, pp.1696-1704, 2007.

[13] T. Noguchi, S. Togashi, and R. Nakamoto, "Short-current pulse-based maximum-power- point tracking method for multiple photovoltaic-and-converter module system," IEEE Transactions on Industrial Electronics, vol. 49, no. 1, pp. 217-223, 2002.

[14] E. Rom'an, R. Alonso, P. Iba nez, S. Elorduizapatarietxe, andD.Goitia, "Intelligent PV module for grid-connected PV systems," IEEE Transactions on Industrial Electronics, vol. 53,no. 4, pp. 1066-1073, 2006.

[15] N. Femia, G. Lisi, G. Petrone, G. Spagnuolo, and M. Vitelli,“Distributed maximum power point tracking of photovoltaic arrays: novel approach and system analysis," IEEE Transactions on Industrial Electronics, vol. 55, no. 7, pp. 2610-2621, 2008.

[16] J. Perlin. From Space To Earth (The Story Of Solar Electricity). Harvard University Press: London, 1999. 